\title{
A Multilevel Model of Responsibility Towards Employees as a Dimension of Corporate Social Responsibility
}

\author{
Aviad Bar-Haim ${ }^{1} \&$ Orr Karassin ${ }^{2}$ \\ ${ }^{1}$ Department of Management and Economics, The Open University of Israel, Israel \\ ${ }^{2}$ Department of Sociology, Political Science and Communication, The Open University of Israel, Israel \\ Correspondence: Orr Karassin, Department of Sociology, Political Science and Communication, The Open \\ University of Israel, 1 University Rd. Rannana, Israel.
}

Received: June 17, 2018 Accepted: July 8, 2018 Online Published: August 21, 2018

doi:10.5539/jms.v8n3p1 URL: https://doi.org/10.5539/jms.v8n3p1

\begin{abstract}
This multilevel study addresses labor relations (LA) and human resource management (HRM) practices within the context of corporate social responsibility (CSR). The study adds to the growing literature on multilevel CSR by addressing the specific aspect of responsibility towards employees through LA-HRM practices in industrial firms. We design a multidimensional model of LA-HRM oriented CSR with the wider institutional environment, industrial setting and organizational setting as antecedents. The model and findings allow for a broad view of factors associated with practices of LA-HRM as important attributes of CSR. The predictive power of the institutional setting as well as industrial setting are shown to be moderately strong, while contrary the research hypothesis the organizational setting generally exhibits weak predictive power. The former finding reinforces the central role of the external environment and actors in firms' internal application of LA-HRM practices and CSR. The later finding suggests that contrary to previous assertions, LA-HRM is generally not within the discretional power and influence of firms, and not a not a key area in the context of firms' voluntary CSR policy but is dominated by externally mandated regulatory requirements.
\end{abstract}

Keywords: CSR, labor relations, HRM, institutional theory, stakeholder theory

\section{Introduction}

Corporate social responsibility (CSR) is a multidimensional concept. Responsibility towards employees is, along with other aspects such as responsibility towards the economy, society environment and product, key to what defines CSR (Carroll, 1979). Responsibility towards employees, achieved through human resource management (HRM) and labor relations (LA), which protect the individual and collective rights and working conditions of employees, are acknowledged as integral to CSR performance (Compa, 2008). However, contrary to environmental or other social responsibilities, LA and HRM practices are under-researched themes of CSR. Exceptional studies are those of Kundu et al. (2015), Sánchez and Benito-Hernández, (2015), Srinivasan and Arora (2015), and Buciuniene and Kazlauskaite (2012). Research on LA-HRM and CSR have moved along different paths, with LA-HRM usually not considered as a unique dimension of CSR. Rather, they have been studied as antecedents to CSR or as outcomes of CSR (see Preuss et al., 2009; and literature review by de Olivera et al., 2013).

This paper focuses on LA-HRM as a unique dimension of CSR, and addresses this topic by developing and testing a multidimensional model of the internal and external antecedents to LA-HRM focused CSR. In so doing we peruse the "first knowledge gap" in CSR research (see Aguinis \& Glavas, 2012, 953 broad literature review), namely: multilevel empirical study of CSR, integrating three levels of analysis, the institutional, industrial and organizational setting.

The research was conducted in the context of the Israeli industrial sector. The Israeli industrial and manufacturing sector in 2013 accounted for $12.5 \%$ of net domestic product. $15 \%$ of the entire workforce is employed by industry. Overall, there are about 1,300 large and medium-sized industrial facilities, out of 21,000, with the remainder comprising small facilities, employing fewer than 50 workers (Bar-Haim \& Karassin, 2015).

Israel lags behind global CSR trends (KPMG, 2013). Corporate culture and governance that promote transparency and voluntary responsibilities have developed only slightly in the last decade. In 2008, Israeli corporations began 
producing GRI-oriented CSR reports. Although industry ranks high among the reporting sectors, the absolute and relative numbers of CSR reports is still very low (KPMG, 2013).

Israeli labor relations have changed over time from a corporatist towards a more pluralist model. As a general rule, Israeli industry is required to comply with a variety of labor related employment, organizational health and safety (OHS) regulations, based on the requirements set out in international agreements (Lurie, 2013). Labor laws specify the rights of salaried employees and grant these more rights than they do contract workers or self-employed individuals (Ben Israel, 2002). Israeli industry is subject to comprehensive legislation concerning non-discrimination and equal opportunities (i.e., The Law of Equal Opportunities at Work 1988), right to associate and collective bargaining (i.e., Collective Bargaining Law 1957) which has been recognized as constitutional under a series of supreme court decisions, minimum wages, social and health benefits (i.e., Minimum Wage Law 1987) and health and safety regulations (under the Law of Safety in the Workplace 1970; and The Law on the Organization of Inspection of Work 1954 which requires firms to devise safety plans and appoint OHS officers.) (Ben Israel, 2002).

\section{A Conceptual Multilevel Model of CSR Focused on LA-HRM}

An enduring question, which has engaged CSR scholars, is what brings about responsible (or irresponsible) behaviors in firms (Vogel, 2007; Crilly et al., 2008; Matten \& Moon, 2008; Aguinis \& Glavas, 2012). Answering this question requires adopting a holistic, interdisciplinary and multilevel view of the firm and its inner and external environments. In recent years some progress has been achieved in both the conceptualization (e.g., Aguilera et al., 2007) and the empirical assessment of multilevel CSR (e.g., Orlitzky et al., 2017; Karassin \& Bar-Haim, 2016). Yet since CSR in itself is a multidimensional concept more focus is needed on the factors affecting the different dimensions of CSR and addressing their related antecedents within the framework of CSR.

We first develop such a multilevel model addressing the LA-HRM dimension of CSR and later go on to empirically validate the model. Figure 1 depicts the conceptual model where three levels are hypothesized as antecedents to LA-HRM practices of CSR. We shall now review each part of the model.

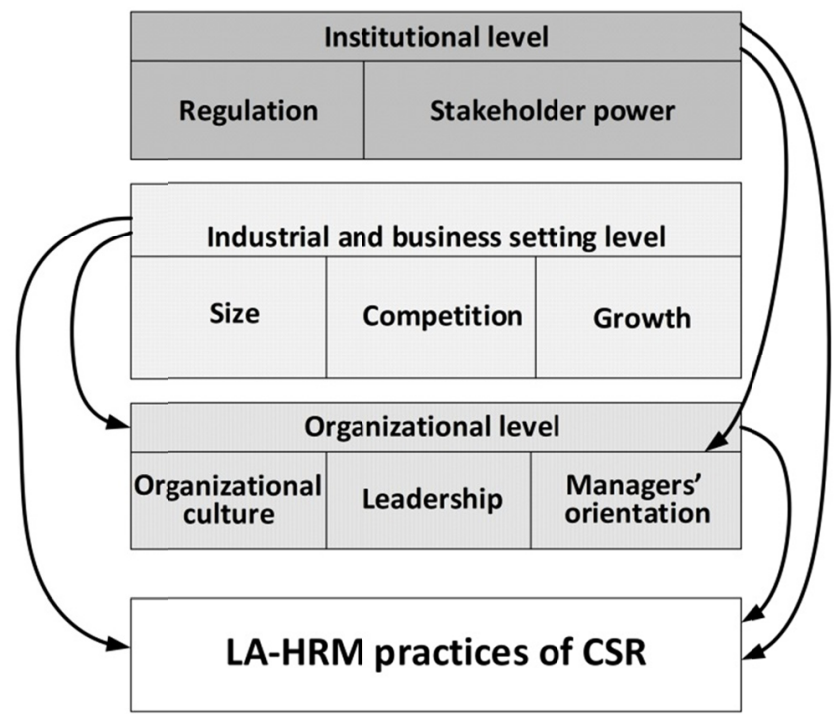

Figure 1. A conceptual multilevel model of CSR focused on LA-HRM

\subsection{The LA-HRM Dimension of CSR}

While CSR maintains an array of definitions and lacks definitional consensus, ethical responsibility (beyond legal duties) towards various corporate stakeholders is a prominent feature of many definitions (Dahlsrud, 2008). Few definitions expressly mention one group of stakeholders over another, yet some note responsibility towards employees with greater focus. For example, The World Business Council for Sustainable Development views CSR as "the continuing commitment by business to behave ethically and contribute to economic development while improving the quality of life of the workforce and their families as well as of the local community and society at large" (Chand, 2006, p. 240). Without doubt, employees are perceived as key stakeholders entitled to responsible treatment by business, beyond the basic requirements of law. 
Beyond definitions, LA-HRM are dominant features of CSR standards and codes. "Employment and industrial relations" is one of the eight thematic chapters of the OECD "Guidelines for Multinational Enterprises" (OECD 2011). These guidelines first adopted in 1976 are the longest standing transnational initiative for the promotion of CSR (Kercher, 2007). While the guidelines cover economic responsibility extensively (in five chapters) and environmental responsibility, the Employment and Industrial Relations Chapter alongside the Human Rights Chapter are the only chapters dealing with the social aspects of business responsibility. LA-HRM issues covered in the guidelines include: freedom of association and collective bargaining, compulsory prohibition of and child labour, non-discrimination, employee-management dialogue and cooperation, work conditions and wages, occupational health and safety and local labour (OECD, 2011 pp. 35-37).

LA practices and decent work indicators are also central to the leading corporate sustainability-reporting tool, the Global Reporting Initiative (GRI) (Levy \& Brown 2012), which is regarded as indicative of measures that relate a commonly accepted representation of LA-HRM in firms (Wilburn \& Wilburn, 2013). To demonstrate: the consolidated set of GRI Sustainability Reporting Standards (2016) encompass 33 standards covering economic environmental and social issues. Out of these standards, nine deal directly with LA-HRM (labour/management relations, occupational health and safety, training and education, diversity and equal opportunity, non-discrimination, freedom of association and collective bargaining, child labour, forced or compulsory labour).

Many private CSR codes and standards focus on LA-HRM primarily or even exclusively. These were developed by private transnational multi-stakeholder organizations including the Fair Labor Association, Worker Rights Consortium, Social Accountability International, Ethical Trading Initiative, Clean Clothes Campaign, and Worldwide Responsible Apparel Production (Compa, 2008). Based on an analysis of key guidelines and standards in the area of CSR, Remišová and Búciová (2012) identify seven main issues relating to CSR towards employees: compensation issues; health and safety; work conditions and corporate social politics; LA and collective bargaining; work dignity and protection against discrimination; individual work relations and internal communication; enforcing employee rights.

While private regulatory instruments and codes relate extensively to LA-HRM in firms, the collective and individual rights or workers and their working conditions are largely protected under International Labor Organization (ILO) conventions, international law and ensuing national legislations. This explains why LA-HRM is a compliance rather than beyond compliance oriented dimension of CSR (Mundlek, 2001). For example, organizational health and safety (OHS) is protected under international law, and particularly the ILO Convention 155, 'Occupational Health \& Safety Convention' and Protocol 155, 1981, set the basic standards for OHS. Although OHS approaches to legislation, regulation and enforcement vary among nations, most countries standards of health a safety conditions are highly codified and based as a minimum on ILO standards (Mundlek, 2001; Montero et al., 2009).

\subsection{The Institutional Level}

The institutional level addresses the environment, in which corporations operate and are required to employ appropriate CSR practices, pursuant to legal, social and cultural pressures (Campbell, 2007). The institutional theory conceptualizes CSR as the responsibility of firms to behave in a fashion that is "desirable in terms of objectives and values of society" (Bowen, 1953, p. 6) and to bring "corporate behavior up to a level where it is congruent with prevailing social norms, values and expectations of performance" (Sethi, 1975, p. 62).

Stakeholder theory, a leading theory of CSR, depicts the external pressures by stakeholders, who are affected by the performance of the corporation, and can influence corporate conduct in direct or informal ways (Freeman, 1984). Both stakeholders are diverse groups in nature, and may include a multitude of actors and groups, acting at the local, national and supra-national levels. Stakeholders are likely to include the firm's customers, employees, suppliers, financial institutions such as banks and insurers, the surrounding community and NGOs as well as regulators (Donaldson \& Preston, 1995; Clarkson, 1995). Despite conflicting interests, the prevailing view has been that stakeholders do influence CSR (Corcoran \& Shackman, 2007; Ditlev-Simonsen et al., 2013; O'Riordan \& Fairbrass, 2014).

A leading perspective on the impact of regulation on CSR has been that strong regulation with a credible threat of enforcement are necessary for voluntary self-regulation, such as CSR to be effective (Lenox \& Nash, 2003; Bansal \& Roth, 2000, Bansal, 2005). Other stakeholders influence the adoption of CSR practices through the market and supply chain (see Mohr et al., 2001). Answering CSR stakeholder expectations may benefit the firm by increasing revenues or decreasing costs, and increasing the firm's competitiveness while promoting innovation (Waddock \& Graves, 1997). Stakeholders also influence firms' social responsibility through public pressure, negative media attention, and expected damage to reputation (van Erp, 2011; Thornton et al., 2009). 


\subsection{The Industrial and Business Setting}

Industrial setting characteristics add mezzo level richness to the analysis of possible precursors to LA-HRM. A firm's industry group is suggested as an important part of the milieu within which organizational policies and practices are framed and executed (Datta et al., 2005). Yet, in a multilevel empirical study, industry group was not found as a significant CSR driver (Orlitzky et al., 2017).

Specific characteristics of industrial setting have been mostly studied in unidimensional models. Market competition is shown to be positively associated with CSR, namely, competitive industries are found to have better social ratings (Fernández, Kranz, \& Santaló, 2010). Yet, the global nature of some industries is documented to place strain on CSR oriented towards LA-HRM (Robinson, 2010). At the same time it is suggested that industries experiencing economic decline, investments in CSR will be cut, while market growth can be a positive driver of CSR (Campbell, 2007), and especially of employee related CSR. At the same time industry market returns are found to be negatively correlated with employee oriented CSR (Godfrey et al., 2010).

\subsection{The Organizational Level}

Within the organizational level three antecedents have often appeared in research: organizational culture, leadership and manager's orientation towards CSR. Of these organizational culture is complex phenomenon with many definitions and measures. Culture includes the vision, values, norms, symbols, language, assumptions, beliefs, practices and habits of the organization and its workforce (Schein, 2006; Needle, 2010). Organizations often have differing subcultures which may at times co-exist or conflict (Schein, 1985; Kotter, 2008; Deal \& Kennedy, 2000). Waldman et al. (2006) are among the few who tried to decode the "organizational cultural DNA" of CSR. This monumental study, identified collectivism as a cultural characteristic that predicts managerial tendency to adopt policies relating to the non-financial interest of various stakeholders.

The importance of Leadership as a potential predictor of CSR performance is explained by the crucial role of managers as organizational leaders in every major change in the corporation (Hemingway, 2005; Aguilera et al., 2007; Waldman et al., 2006). Nevertheless, there is insufficient knowledge on the effect of leadership on CSR (Strand, 2011; Angus-Leppan et al., 2009; Waldman \& Siegel, 2008).

Managers' commitment to CSR is considered likely to have a strong influence on firm-level CSR engagement (Weaver et al., 1999) and outcomes (Hemingway, 2005; Aguilera et al., 2007). Both instrumental (e.g., the perception that CSR is good for business) and normative (e.g., a sense of responsibility and duty) reasons have been found to be possible motivations for CSR (Bansal \& Roth, 2000, Graafland et al., 2007, Mudrack, 2007). One such study has shown that organizations that undertake CSR because of external influences, without commitment by management, engage in "decoupled CSR activities," which are disconnected from ongoing core business activities (Weaver et al., 1999).

\section{The Model and Research Hypotheses}

Based on the review, we develop a multilevel model of CSR with LA-HRM performance as the dependent variable. The upper institutional dimension incorporates regulatory and stakeholder pressures. The industrial setting and profile dimension includes competition and growth as industrial group traits and size as mezzo level corporate profile trait. The organizational dimension incorporates organizational culture, leadership and managers' orientation (see Figure 2).

The following hypotheses are derived from the model:

H1: All three levels, the institutional, industrial setting and organizational level are expected to be positively associated with CSR focused on LA-HRM scale.

H2: Regulatory pressures are expected to be the most dominant factor in contributing to LA-HRM because of the compliance nature of this dimension of CSR as discussed above.

H3: The institutional level and industrial and business setting indirectly influence LA-HRM scale, through their influence on the organizational level (the institutional level only on managers' orientation), in addition to their direct impact. This indirect supposed impact occurs because they limit the degrees of freedom on internal organizational culture, leadership and managers' orientation. For example, size may influence the strength and diversity of organizational culture and sub-cultures.

\section{Method}

\subsection{The Sample}

The model was tested in 11 medium and large Israeli industrial facilities (the "facility sample"). We interviewed 54 top managers of these facilities ("the managerial sample" and completed questionnaires by 412 workers in these 
facilities ("the workers sample"). The questionnaire and interviews were conducted in 2013-2014 in person at the facility site.

The industrial sectors covered in the "facility sample" are chemical, metal, computer components, electronic, and optical equipment, rubber and plastic, machinery and equipment. Most of the firms are privately held and few are publicly traded. Most of the firms export over $40 \%$ of their products. Majority of them operate in saturated markets, with national and international competitors, the rest in smaller markets with fewer competitors. The median number of employees in the explored firms was 244,70 of which are outsourced positions. Therefore, the median firm in the study is of small size nearing medium in Israeli terms. The "facility sample" was based on availability, where only very low $(\sim 10 \%)$ of the industrial enterprises that we planned to explore responded and agreed to participate. However, the above characteristics of the sample and its geographical coverage of all the regions of the country, allow us to believe that it is an appropriate case for describing CSR in Israel. The "managerial sample" $(\mathrm{n}=54)$ included 4-6 senior managerial positions in each enterprise (always including CEO, CFO and HRM Officer). $28 \%$ were female and $72 \%$ were male. The "workers sample" $(n=412)$ was composed of $\sim 40$ workers in each facility, who were selected randomly. $36 \%$ were female and $64 \%$ were male.

\subsection{Data Set}

The data collected from different entities (industrial enterprises, managers, and workers) at different levels (institutional, organizational, performance), display different measurement levels. To estimate the model at the same measurement level of all variables and enable multivariate statistics, we employed the same method as we did in the study on Corporate Environmental Responsibility (Karassin \& Bar-Haim, 2016). We assigned to 412 workers the mean scores of the 54 managers. Similarly, we assigned to the workers sample the scores of the regulatory records of the 11 enterprises. This expansion method (the reverse of the common use of aggregation method) produced a data set of 412 of workers who have the additional background or external properties of the scores of their managers and of their enterprise. To check for obvious possible biases derived from the considerable differences of samples' size and variances, we aggregated the model's variables mean to the managers sample (N-54) and the facility sample $(\mathrm{N}=11)$. Then we examined the patterns of parametric (Pearson's r) and non-parametric (Spearman's rank-order $\mathrm{r}_{\mathrm{S}}$ ) correlations among the model' variables. Except for 2 out of 105 pairs of correlations in the model, there were no significant differences between the correlation matrices at the level of 412 respondents, that of the level of 54 managers, and at the level of 11 enterprises. Of course, a larger enterprise and managers samples would reduce the risk of bias in the expansion procedure. But the consistent and stable patterns of the correlation matrices reduce the concern for the reliability of the statistical results.

\subsection{Method}

To test the model, we performed an unweighted least squares (ULS) regression in a structural equation model (SEM), using IBM AMOS 22 statistical package. This method of estimation is required because of the non-linearity of almost all the variables in the model. Fitting the model by ULS has the advantage of no need of distributional assumptions. ULS, however, does not provide a significance test for the estimates, and therefore an approximation is needed. The ordinary least squares (OLS) method is used as an approximation of significance in testing ULS estimates, as accepted solution (Millsap \& Maydeu-Olivares, 2009; Vinzi et al., 2010). The standardized effect (estimate) of path coefficients of less than \pm 0.30 is considered weak or negligible. The effect of path coefficients above \pm 0.30 and below \pm 0.70 is defined as medium, and of path coefficients of \pm 0.70 and above as strong.

\subsection{Measurement}

\subsubsection{The Dependent Variable: Scale of CSR Practices Focused on LA-HRM}

The LA-HRM scale was designed as a 5 item scale covering: lost days per worker due to work related sickness or injury; percentage of contract workers; Percentage of employees who work under a collective agreement; Percentage of employees belonging to a labor union and Number of annual paid hours for training. These indicators cover 5 out of the 7 aspects of CSR practices of LA-HRM as discussed above. Missing aspects are diversity and equal opportunity and equal remuneration. Data collected for the equal remuneration indicator was incomplete, and therefore could not be included in the analysis. Data relating to diversity and equal opportunity is included in the sample description, but not as an integral part of the dependent variable. The scale was built by Optimal Scaling procedure because the indicators vary in content and measures. (Note 1) 
Table 1. Standardized optimal LA-HRM scale

\begin{tabular}{|c|c|c|c|c|c|c|c|}
\hline Measure of & Item & Weight & $\mathbf{N}$ & Min. & Max. & Mean & SD \\
\hline $\begin{array}{l}\text { Equal remuneration and } \\
\text { employment type }\end{array}$ & $\%$ Contract workers & .654 & 412 & .01 & 30,00 & 9.02 & 10.13 \\
\hline collective bargaining & $\%$ Employees covered by collective agreement & .846 & 412 & .0 & 100.0 & 58.77 & 48.63 \\
\hline Freedom of association & $\%$ Employees belonging to a labor union & .965 & 412 & .0 & 100.0 & 16.42 & 34.00 \\
\hline $\begin{array}{l}\text { Health and safety in work } \\
\text { place }\end{array}$ & \# Lost days per worker & 1.000 & 412 & .04 & 17.71 & 1.77 & 4.45 \\
\hline \multirow[t]{4}{*}{$\begin{array}{l}\text { Occupational education and } \\
\text { training }\end{array}$} & $\begin{array}{l}\text { \# Annual hours of occupational training per } \\
\text { worker }\end{array}$ & 1.000 & 412 & .01 & 105.00 & 14.47 & 26.53 \\
\hline & LA-HRM optimal scale & & 412 & -.47 & 3.33 & .00 & 1.00 \\
\hline & Cronbach's Alpha & \multicolumn{4}{|c|}{$\%$ of Variance } & & \\
\hline & 4.465 & \multicolumn{3}{|c|}{89.296} & & & \\
\hline
\end{tabular}

\subsubsection{Regulatory Demands Scale (Institutional Level Variable)}

Regulatory demands concerning LA-HRM have two facets. First, the regulatory conditions and second the concrete enforcement action taken against a firm. The regulatory conditions, comprising of the legal conditions and requirements set by regulators on various labor and employment issues are typically common to all industrial facilities in a given region. These May vary slightly due to particular conditions set by industrial collective agreements applying to certain types of facilities.

Conversely, enforcement actions are particular to every firm facility. Therefore, enforcement actions are chosen to represent regulatory demands. Organizational health and safety (OHS) regulations are the most commonly monitored LA-HRM regulations in our sample and hence serves as reliable proxy. OHS inspections may occur following reported workplace accidents, or as routine inspections. In certain cases, when inspections uncover severe non-compliance with health and safety conditions, which is not corrected, administrative proceedings can be initiated. Data from OHS enforcement actions (Table 2) was provided by the Ministry of Economy for each firm facility.

Table 2. Standardized optimal LA-HRM regulatory demands scale (Note 2)

\begin{tabular}{lllllll}
\hline Items & Weights & N & Min. & Max. & Mean & SD \\
\hline OHS random inspections & 1.00 & 412 & .00 & 12.00 & 4.06 & \\
OHS administrative proceeding & 1.00 & 412 & .00 & 3.00 & 1.09 & .95 \\
OHS accident related inspections & 1.00 & 412 & .00 & 48.00 & 20.96 & 16.04 \\
LA-HRM Regulatory demands optimal scale & & 412 & -3.33 & .31 & .00 & 1.00 \\
\hline
\end{tabular}

\begin{tabular}{lll}
\hline Cronbach's Alpha & Eigenvalue & \% of Variance \\
\hline 1.000 & 3.000 & 100.000 \\
\hline
\end{tabular}

\subsubsection{Regulatory and Stakeholder Power (Institutional Level Variables)}

Both regulatory as well as stakeholder power are assessed by managers' perception of the degree of influence of external actors and their ability to impact the ongoing activities or future of the firm. This may impact the response of firms to the actor's interests and demands (Mitchell et al. 1997; Parent and Deephouse, 2007). Among stakeholders were included customers, workers, suppliers, and community and NGOs and financial institutions (banks and insurance companies).

Regulatory power and stakeholders' power (Table $3 \&$ Table 4) are assessed by managers' perceptions of the degree of influence of these external actors on the ongoing activities or the future of the firm (on a Likert-type scale of 4 categories, from $1=$ no influence to $4=$ a great deal of influence).

Table 3. Regulatory power variable*

\begin{tabular}{|c|c|c|c|c|}
\hline Item & & $\mathbf{N}$ & Mean & SD \\
\hline $\begin{array}{l}\text { Degree of influence of the regulator on the ongoing activities or the } \\
\text { future of the firm }\end{array}$ & Single item & 412 & 3.40 & 0.49 \\
\hline
\end{tabular}

* The distribution is not normal according to the Kolmogorov-Smirnov one-sample test. 
Table 4. Stakeholders' power variable*

\begin{tabular}{lllll}
\hline Item & Reliability & N & Mean & SD \\
\hline Customers & Cronbach $\alpha=0.71(2$ items $)$ & 412 & 3.38 & 0.48 \\
Workers & Spearman-Brown $=0.55(2$ items $)$ & 412 & 3.28 & 0.27 \\
Suppliers & Cronbach $\alpha=0.60(2$ items $)$ & 412 & 2.61 & 0.46 \\
Community & Cronbach $\alpha=0.69(2$ items $)$ & 412 & 2.42 & 0.52 \\
Financial & Cronbach $\alpha=0.69(2$ items $)$ & 412 & 2.09 & 0.74 \\
\hline
\end{tabular}

* The distribution is not normal according to the Kolmogorov-Smirnov one-sample test.

\subsubsection{Industrial and Business Setting Level Variables}

Three industrial and business setting variables are included in the model: company size, competition and growth (Table 5). Company size relates to the total number of employees working for the company. The degree of market competition relates to both local and international competition. Rate of growth is based on firms' fiscal data for the four previous years.

Table 5. Industrial and business setting*

\begin{tabular}{llllll}
\hline Item & $\mathbf{N}$ & Min. & Max. & Mean & SD \\
\hline Size (N of employees) & 412 & 64 & 3305 & 710 & 986 \\
Competitors (1-no, 2-few,3-lot) & 412 & 1.00 & 3.00 & 2.18 & .57 \\
Growth (1-no,2-yes) & 412 & 1.00 & 2.00 & 1.58 & .49
\end{tabular}

* The distribution is not normal according to the Kolmogorov-Smirnov one-sample test.

\subsubsection{Organizational Culture (Organizational Level Variable)}

The scale developed for organizational culture is based on 24 Likert-type items from the Organizational Culture Assessment Instrument (OCAI), developed by Cameron and Quinn (1999), and the Organizational Cultural Inventory (OCI), developed by Cooke and Lafferty (1989). We were able to identify 7 reliable sub-cultures: familial, communitarian, innovative, learning, competitive and goal-driven, authoritative, and human resource development. However, due to limitations on degrees of freedom of our sample, only an overall additive scale of these seven subscales is used (see table 6). The data for the organizational culture scale were derived from the workers questionnaire.

Table 6. Organizational culture scale*

\begin{tabular}{|c|c|c|c|c|c|}
\hline Item & Reliability & Item-Total correlation & $\mathbf{N}$ & Mean & SD \\
\hline $\begin{array}{l}\text { Familial } \\
\text { Sample item: "Our plant is like a family." }\end{array}$ & $\begin{array}{l}\text { Cronbach } \alpha=0.79 \\
(5 \text { items })\end{array}$ & 0.69 & 412 & 2.97 & 0.60 \\
\hline $\begin{array}{l}\text { Communitarian } \\
\text { Sample item: "Our plant emphasizes responsibility to } \\
\text { the community and the surrounding environment." }\end{array}$ & $\begin{array}{l}\text { Cronbach } \alpha=0.74 \\
\text { (5 items) }\end{array}$ & 0.78 & 412 & 2.92 & 0.51 \\
\hline $\begin{array}{l}\text { Innovative } \\
\text { Sample item: "Our plant regularly experiences } \\
\text { changes and innovations." }\end{array}$ & $\begin{array}{l}\text { Cronbach } \alpha=0.73 \\
\text { (4 items) }\end{array}$ & 0.69 & 412 & 3.02 & 0.55 \\
\hline $\begin{array}{l}\text { Learning } \\
\text { Sample item: "Our plant encourages us to learn our } \\
\text { lessons from environmental accidents and improve." }\end{array}$ & $\begin{array}{l}\text { Spearman-Brown } \\
=0.89(2 \text { items })\end{array}$ & 0.52 & 412 & 3.19 & 0.62 \\
\hline $\begin{array}{l}\text { Competitive and goal-driven Sample items: } \\
\text { "Workers in the plant are very competitive and } \\
\text { goal-oriented." "Our main concern at the plant is that } \\
\text { tasks are carried out." }\end{array}$ & $\begin{array}{l}\text { Cronbach } \alpha=0.71 \\
\text { (8 items) }\end{array}$ & 0.48 & 412 & 2.96 & 0.41 \\
\hline $\begin{array}{l}\text { Authoritative } \\
\text { Sample item: "Plant managers require us to obey and } \\
\text { do as we are told." }\end{array}$ & $\begin{array}{l}\text { Cronbach } \alpha=0.61 \\
(5 \text { items })\end{array}$ & 0.42 & 412 & 2.99 & .42 \\
\hline $\begin{array}{l}\text { Human resource development Sample item: "Our } \\
\text { plant emphasizes employee development and } \\
\text { professional advancement." }\end{array}$ & $\begin{array}{l}\text { Cronbach } \alpha=0.81 \\
(3 \text { items })\end{array}$ & 0.72 & 412 & 2.75 & 0.70 \\
\hline Overall organizational culture scale & $\begin{array}{l}\text { Cronbach } \alpha= \\
0.85 \\
\text { (7 items) }\end{array}$ & & 412 & 2.97 & 0.40 \\
\hline
\end{tabular}

\footnotetext{
* The distribution is normal according to the Kolmogorov-Smirnov one-sample test.
} 


\subsubsection{Organizational Leadership (Organizational Level Variables)}

Empirical research has found the distinction between transformational and transactional (rewarding) types of organizational leadership as more useful than other categorizations in predicting CSR behaviors (Groves and LaRocca, 2011). Transactional leadership in organizations is a managerial style by which the leader promotes employee compliance through rewards and a "psychological contract." By contrast, transformational leaders collaborate with employees to identify needed changes in the organization and act to create a vision for guiding change through inspiration (Avolio et al., 1999). The distinction between transformative and transactional (rewarding) leadership is applied in the model (Figure 1). The leadership scales are based on 7 Likert-type items from the widely applied Multifactor Leadership Questionnaire (MLQ) (Avolio et al., 1999; amended by Ling et al., 2008). See table 7.

Table 7. Organizational leadership scales*

\begin{tabular}{|c|c|c|c|c|}
\hline Item & Reliability & $\mathbf{N}$ & Mean & SD \\
\hline $\begin{array}{l}\text { Transformational } \\
\text { Sample item: "My direct supervisor helps workers develop } \\
\text { their strengths" }\end{array}$ & $\begin{array}{l}\text { Cronbach } \alpha=0.88 \\
(5 \text { items })\end{array}$ & 412 & 12.05 & 2.57 \\
\hline $\begin{array}{l}\text { Transactional } \\
\text { Sample item: "My direct supervisor clarifies to workers } \\
\text { what they get if they meet the goals and targets that are } \\
\text { assigned to them" }\end{array}$ & $\begin{array}{l}\text { Cronbach } \alpha=0.51 \\
\text { (2 items) }\end{array}$ & 412 & 8.42 & 1.95 \\
\hline
\end{tabular}

* The distribution is not normal according to the Kolmogorov-Smirnov one-sample test.

\subsubsection{Managers' Orientation (Organizational Level Variable)}

An additive scale of managers' attitudes and behavior towards CSR performance (Table 8) was constructed based on 3 Likert-type items from the managerial sample.

Table 8. Managers' orientation scale*

\begin{tabular}{|c|c|c|c|c|c|}
\hline Item & $\mathbf{N}$ & Min. & Max. & Mean & SD \\
\hline Management emphasizes receiving credible information on CSR performance & 52 & 2 & 4 & 3.37 & .69 \\
\hline Management uses various strategies to advance CSR goals & 54 & 1 & 4 & 2.85 & .98 \\
\hline \multirow{2}{*}{$\begin{array}{l}\text { Management is expected to achieve CSR performance in addition to } \\
\text { economic performance }\end{array}$} & 54 & 1 & 4 & 3.17 & .86 \\
\hline & Reliability & & $\mathbf{N}$ & Mean & SD \\
\hline Managers' Orientation scale & Cronbach $\alpha$ & (3 items) & 412 & 3.33 & 0.32 \\
\hline
\end{tabular}

\section{Analysis and Results}

Table 9. Standardized ULS regression weights of direct path coefficients

\begin{tabular}{|c|c|c|}
\hline Predictors & Dependent variable & Path coefficient \\
\hline \multicolumn{3}{|l|}{ Institutional level } \\
\hline Regulatory demands & CSR focused LA-HRM & $7.033^{*}$ \\
\hline Regulator power & “ & $3.472^{*}$ \\
\hline Customers power & “ & 0 \\
\hline Workers power & “ & $-.308^{*}$ \\
\hline Suppliers power & “ & 0 \\
\hline Community power & “ & $-4.343^{*}$ \\
\hline Financial institutions power & “ & $-.251^{*}$ \\
\hline \multicolumn{3}{|c|}{ Industrial and Business Setting } \\
\hline Size & CSR focused LA-HRM & $2.610^{*}$ \\
\hline Competition & “ & $.650^{*}$ \\
\hline Growth & “ & $-1.551^{*}$ \\
\hline \multicolumn{3}{|l|}{ Organizational level } \\
\hline Transactional leadership & CSR focused LA-HRM & .043 \\
\hline Transformational leadership & “ & .309 \\
\hline Organizational culture & “ & .099 \\
\hline Managers' orientations & “ & $-8.521^{*}$ \\
\hline
\end{tabular}

\footnotetext{
" p-value $<\mathbf{0 . 0 1}$ according to OLS approximation of ULS estimates.
} 
Table 10. Standardized ULS regression weights of indirect path coefficients

\begin{tabular}{|c|c|c|}
\hline Predictors & Dependent variable & Path Coefficient \\
\hline Regulatory demands & Managers' orientations & $.775^{*}$ \\
\hline Regulator power & “ & $.415^{*}$ \\
\hline Customers power & “ & 0 \\
\hline Workers power & “ & $-.375^{*}$ \\
\hline Suppliers power & “ & 0 \\
\hline Community power & “ & $-.492 *$ \\
\hline Financial institutions power & “ & $-.050 *$ \\
\hline Size & Managers' orientations & $.322^{*}$ \\
\hline Competition & “ & $.021^{*}$ \\
\hline Growth & “ & $-.186^{*}$ \\
\hline Size & Transactional leadership & $.120 * *$ \\
\hline Size & Transformational leadership & $.147^{*}$ \\
\hline Size & Organizational culture & $.251^{*}$ \\
\hline Competition & Transactional leadership & $-.840 *$ \\
\hline Competition & Transformational leadership & $-.829^{*}$ \\
\hline Competition & Organizational culture & $-.659^{*}$ \\
\hline Growth & Transactional leadership & .061 \\
\hline Growth & Transformational leadership & .073 \\
\hline Growth & Organizational culture & .085 \\
\hline
\end{tabular}

The prediction power of our model is very high (Pseudo R-Square Cox and Snell $=.991$ ), and its fitness is high as well according to GFI. The direct effects of the institutional level are mixed. Regulatory pressure (demands and power) have a significant high positive effect on the dependent variable, while stakeholders have either strong negative effects (community power), or small (workers and financial stakeholders) or zero effects (suppliers and customers). The organizational and business setting has a strong effect on the dependent by the variables of size and competition, and a negative strong effect of the growth variable. The direct effect of the organizational level is negligible for organizational culture and organizational leadership, and negatively strong for manager's orientation. The effects of the institutional level variables, especially on the managers' orientation are positively strong to medium for the regulation variables, and mixed both in strength and direction for stakeholder power.

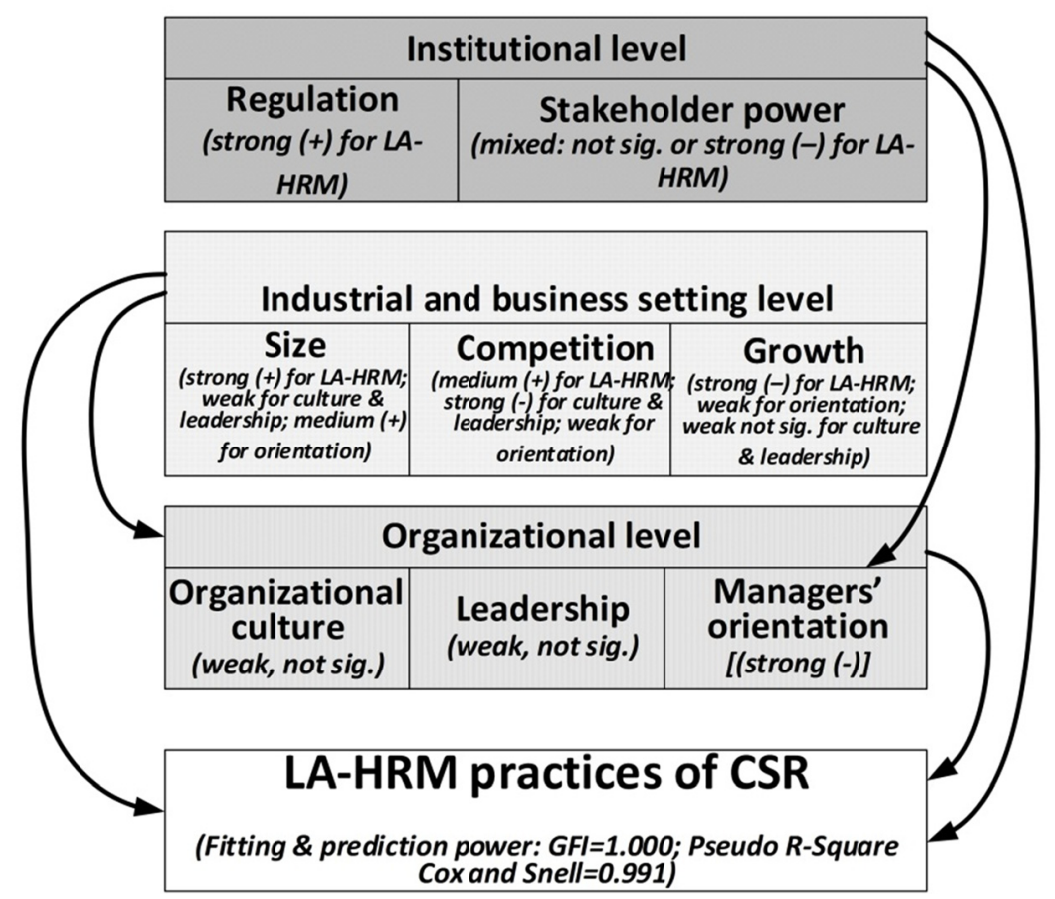

Figure 2. Empirical results of the theoretical model of CSR focused on LA-HRM 


\section{Discussion}

We set out to assess the multidimensional effects of several sets of hypothesized factors on CSR practices focused on LA-HRM. The mixed effect of the institutional level only partially confirmed H1. While the medium-high positive direct and indirect effects of regulatory pressures affirms $\mathrm{H} 1$ and $\mathrm{H} 2$, the negative relationship between some of the stakeholder power and the dependent variable is contrary to H1. The mixed findings regarding the industrial and business setting (Strong positive effect of size and medium positive effect of competition along strong negative effect of growth) partially confirm H1. The finding of the negligible effects of organizational culture and leadership in the achievement of LA-HRM, as well as the strong negative effect of managers' orientation on the dependent variable, are contrary to H1, and will be discussed further bellow.

Regulatory demands are found to be strongly and positively associated with LA-HRM, and regulatory power is found as reasonably associated with the dependent variable. This confirms previous research that CSR behaviour is responsive to external regulatory pressures (Lenox \& Nash, 2003; Bansal, 2005). This finding accentuates that LA-HRM in the context of CSR are compliance, rather than beyond compliance, oriented. Although LA-HRM actions are carried out in employing organizations, institutional actors such as governments play an important role in the oversights and monitoring LA-HRM practices (French \& Wokutch, 2005; Karnani, 2007). The definition of LA-HRM as described above and the impact of regulatory demands and power as antecedents emphasize the prominence of the compliance nature of LA-HRM practices in relation to CSR.

The finding of the negative relationship of community stakeholders to LA-HRM confirms previous assertions in literature that stakeholders may hold conflicting interests regarding aspects of CSR. Although they may impact the performance of the firm, they can do so in a way that negatively impacts certain aspects of CSR performance, while at the same time they may positively impact other aspects, such as environmental responsibility (Ditlev-Simonsen et al., 2013; Freeman, 1984). The general finding of the null relationships of other stakeholders with the dependent variable confirms the assertion that LA-HRM particularly are seen as non-strategic aspects of the firms' CSR performance (Rodriguez \& Gomez, 2009). The low impact of workers as stakeholders on LA-HRM, extenuates the above mentioned external conditionality on HRM as a CSR attribute, and the constraints on HR managers discussed bellow.

The findings of the negligible effect of organizational culture and leadership in conjuncture with the strong negative effect of managers' orientation on LA-HRM, contradict hypotheses H1. Three possible interrelated explanations for these findings may be of relevance. The first is the strong external compliance oriented nature of LA-HRM in the context of CSR. The second relates to the status of HR managers and LA-HRM in the power structure of the management system of the firm. The third is a possible decoupling of CSR from LA-HRM in particular. All three explanations accentuate the enigmatic function of LA-HRM in the decision-making of corporate managers attempting to promote CSR.

Many of the LA-HRM practices are derived directly or indirectly from international and national standards and regulations. As discussed previously, the compliance oriented nature of LA-HRM in the context of CSR generally, and in our study specifically (four out of five items in the scale are compliance oriented), imposes a limit on the degrees of freedom of intra-organizational mechanisms. From this perspective, the fact that organizational culture and leadership do not hold leeway and power over these factors is understandable. For example, strong LA-HRM external compliance may reduce organizational culture codes of innovation or HR development, or transformational leadership initiatives in this CSR field.

The former explanation is strengthened by studies that have demonstrated that LA-HRM practices and decision making are only partially within the authority and direct control of managers and HR officers (See: Novicevic et al., 2011). In most cases, managers have less freedom in dealing with LA-HRM issues compared to other managerial domains, such as finance and technology (Boselie et al., 2009). Their freedom is constrained by the institutional environment that interplays the power of unions, varying political factors and conditions (Staehle \& Schirmer, 1992). Also, internally, the LA-HRM function is less influential on management boards, though its importance in multinational firms is more salient (Sumetzberger, 2005; Jackson \& Rathert, 2016). Its dual function in advancing firm's interests as well as responding to its workforce needs, weakens its impact internally. It is our suggestion that these constraints and the ambivalence of LA-HRM facet may impede CSR-motivated managers from attaining high performance in this area. In this sense hypothesis $\mathrm{H} 3$ is partially confirmed since regulatory pressures are found to positively constrain to a medium degree managers' orientation (see Table 10), although the total impact (direct and indirect is still a negative term between managers' orientation and LA-HRM practices of CSR.

The negative effect of managers' orientation on LA-HRM may point to a gap between managers' proclaimed attitudes, motivations and strategies regarding CSR and their commitment to achieving impacts on LA-HRM 
issues. This gap between promising policy statements and poor implementation of programs and impacts is labelled in the literature as "decoupling" (Graafland \& Smid, 2016). Institutional theory suggests that the main reason for companies to decouple is the tension between a company, having to gain social legitimacy, while facing pressures to maintain efficiency and profitability (Graafland \& Smid, 2016). The quest for social legitimacy can make it attractive to uphold a public image of a positive social actor, without committing to the necessary actions (Harrison \& Freeman, 1999). Several studies found that such legitimacy pressures result in decoupling processes whereby corporate responses to external demands remain more symbolic than substantive (Jamali, 2010; Okhmatovskiy \& David, 2012). In the case of LA-HRM performance, the motivation for decoupling may even be stronger because of the less visible nature of LA-HRM compared to other environmental, social or product aspects of CSR. In other words, managers may find it easier to create an image of obligation to CSR without taking measures to address LA-HRM in practice.

\section{Conclusion}

Although our limited sample size and national focus necessitates caution in generalizing our results, the multilevel explanatory model of antecedents to LA-HRM performance is highly robust. LA-HRM in the context of CSR is the most highly impacted by the institutional level variables. Even from a LA-HRM perspective, considered generally to be less visible of CSR facets, LA-HRM practices of CSR remain highly externally dependent. It is quite clear that the role of external pressures is important to achieving performance in the field of LA-HRM, although not all stakeholder pressures may positively contribute it. This effect contrasts with the limited power and freedom that internal organizational mechanisms hold over LA-HRM. Organizational culture and leadership are found not to have a direct impact on improved LA-HRM performance, although further research would be required to assert whether this effect is generalizable. Managers' orientation negative association with LA-HRM accentuates the ambivalent nature of LA-HRM as well as the ambivalence of managers towards its improvement.

From a managerial perspective, reducing the ambiguity of LA-HRM is achievable through strict compliance with regulatory demands in this area. In most developed countries, LA-HRM regulation, usually based on international standards, is encompassing. Therefore, in most cases, compliance with regulations will be sufficent to attain LA-HRM CSR goals and a reputation of a responsible employer. However, room does exist for beyond compliance achievements in the field of LA-HRM, in the form of strategic HRM practices. These may include activities such as training for skills, developing career trajectories and job enrichment programs for workers, consultation with workers, promoting quality of working life and many other HRM initiatives that embody CSR.

\section{References}

Aguilera, R. V., Rupp, D. E., Williams, C. A., \& Ganapathi, J. (2007). Putting the S back in corporate social responsibility: A multilevel theory of social change in organizations. Academy of Management Review, 32(3), 836-863. https://doi.org/10.5465/amr.2007.25275678

Aguinis, H., \& Glavas, A. (2012). What we know and don't know about corporate social responsibility a review and research agenda. Journal of Management, 38(4), 932-968. https://doi.org/10.1177/0149206311436079

Aguinis, H., \& Kraiger, K. (2009). Benefits of training and development for individuals and teams, organizations, and society. Annual Review of Psychology, 60, 451-474. https://doi.org/10.1146/annurev.psych.60.110707.163505

Angus-Leppan, T., Metcalf, L., \& Benn, S. (2010). Leadership styles and CSR practice: an examination of sensemaking, institutional drivers and CSR leadership. Journal of Business Ethics, 93(2), 189-213. https://doi.org/10.1007/s10551-009-0221-y

Avolio, B. J., Bass, B. M., \& Jung, D. I. (1999). Re-examining the components of transformational and transactional leadership using the Multifactor Leadership. Journal of Occupational and Organizational Psychology, 72(4), 441-462. https://doi.org/10.1348/096317999166789

Bansal, P. (2005). Evolving sustainably: A longitudinal study of corporate sustainable development. Strategic Management Journal, 26(3), 197-218. https://doi.org/10.1002/smj.441

Bansal, P., \& Roth, K. (2000). Why companies go green: A model of ecological responsiveness. Academy of Management Journal, 43(4), 717-736.

Bar Haim, A., \& Karassin, O. (2015). Corporate Social Responsibility in Israeli Industry: Uncovering The Determinants Final Report Research Report March 2015. Retrieved from: ttps://www.researchgate.net/publication/309619033_CORPORATE_SOCIAL_RESPONSIBILITY_IN_IS RAELI_INDUSTRY_UNCOVERING_THE_DETERMINANTS (last accessed 26/6/2018). 
Ben Israel, R. (2002). Labor Law Volume II. The Open University of Israel Publishing: Tel-Aviv.

Boselie, P., Brewster, C., Paauwe, J., Boselie, P., Brewster, C., \& Paauwe, J. (2009). In search of balance-managing the dualities of HRM: an overview of the issues. Personnel Review, 38(5), 461-471. https://doi.org/10.1108/00483480910977992

Bowen, H. R. (1953). Social Responsibility of the Businessman. New York: Harper and Row.

Buciuniene, I., \& Kazlauskaite, R. (2012). The linkage between HRM, CSR and performance outcomes. Baltic Journal of Management, 7(1), 5-24. https://doi.org/10.1108/17465261211195856

Cameron, K. S., \& Quinn, R. E. (2005). Diagnosing and changing organizational culture: Based on the competing values framework. John Wiley \& Sons.

Campbell, J. L. (2007). Why would corporations behave in socially responsible ways? An institutional theory of corporate social responsibility. Academy of Management Review, 32(3), 946-967. https://doi.org/10.5465/amr.2007.25275684

Carroll, A. B. (1979). A three-dimensional conceptual model of corporate social performance. Academy of Management Review, 4, 497-505. https://doi.org/10.5465/amr.1979.4498296

Chand, M. (2006). 'The Relationship Between Corporate Social Performance and Corporate Financial Performance: Industry Type as a Boundary Condition'. The Business Review, 5(1), 240-245.

Clarkson, M. E. (1995). A stakeholder framework for analyzing and evaluating corporate social performance. Academy of Management Review, 20(1), 92-117.https://doi.org/10.5465/amr.1995.9503271994

Compa, L. (2008). Corporate social Responsibility and Workers' Rights. Comparative Labour Law \& Policy Journal, 30, 1-10.

Cooke, R. A., \& Lafferty, J. C. (1989). Organizational Culture Inventory. Plymouth MI Human Synergistics.

Corcoran, D. J., \& Shackman, J. D. (2007). A Theoretical and Empirical Analysis Of The Strategic Value Of Beyond Compliance Occupational Health And Safety Programs. Journal of Business Strategies, 24(1), 49-68.

Dahlsrud, A. (2008). How corporate social responsibility is defined: an analysis of 37 definitions. Corporate social responsibility and environmental management, 15(1), 1-13. https://doi.org/10.1002/csr.132

Datta, D. K., Guthrie, J. P., \& Wright, P. M. (2005). Human resource management and labor productivity: does industry matter?. Academy of Management Journal, 48(1), 135-145. https://doi.org/10.5465/amj.2005.15993158

Deal, T. E., \& Kennedy, A. A. (2000). Corporate Cultures, Perseus.

Deal, T. E., \& Kennedy, A. A. (2000). Corporate cultures: The rites and rituals of corporate life. Da Capo Press.

Ditlev-Simonsen, C., \& Wenstøp, F. (2013). How stakeholders view stakeholders as CSR motivators. Social Responsibility Journal, 9(1), 137-147. https://doi.org/10.1108/17471111311307868

Donaldson, T., \& Preston, L. E. (1995). The stakeholder theory of the corporation: Concepts, evidence, and implications. Academy of Management Review, 20(1), 65-91. https://doi.org/10.5465/amr.1995.9503271992

Fernández-Kranz, D., \& Santaló, J. (2010). When necessity becomes a virtue: The effect of product market competition on corporate social responsibility. Journal of Economics \& Management Strategy, 19(2), 453-487. https://doi.org/10.1111/j.1530-9134.2010.00258.x

Freeman, R. E. (1984). Strategic management: A stakeholder approach (Pitman Series in Business and Public Policy). Harpercollins College Div.

French, J. L., \& Wokutch, R. E. (2005). Child workers, globalization, and international business ethics: A case study in Brazil's export-oriented shoe industry. Business Ethics Quarterly, 15(4), 615-640. https://doi.org/10.5840/beq200515443

Graafland, J., \& Smid, H. (2016). Decoupling Among CSR Policies, Programs, and Impacts An Empirical Study. Business \& Society, 7650316647951.

Graafland, J., Kaptein, M., \& der Duijn Schouten, C. (2007). Conceptions of God, Normative Convictions, and Socially Responsible Business Conduct An Explorative Study Among Executives. Business \& Society, 46(3), 331-368. https://doi.org/10.1177/0007650306296085

GRI. (2013). G4 Sustainability Reporting Guidelines - Part 1: Reporting Principles and Standard Disclosures 
(techreport). Global Reporting Initiative. http://doi.org/https://www.globalreporting.org/resourcelibrary/G3-Guidelines-Incl-

Groves, K. S., \& LaRocca, M. A. (2011). An empirical study of leader ethical values, transformational and transactional leadership, and follower attitudes toward corporate social responsibility. Journal of Business Ethics, 103(4), 511-528. https://doi.org/10.1007/s10551-011-0877-y

Harrison, J. S., \& Freeman, R. E. (1999). Stakeholders, social responsibility, and performance: Empirical evidence and theoretical perspectives. Academy of Management Journal, 42(5), 479-485.

Hemingway, C. A. (2005). Personal values as a catalyst for corporate social entrepreneurship. Journal of Business Ethics, 60(3), 233-249. https://doi.org/10.1007/s10551-005-0132-5

Jackson, G., \& Rathert, N., (2016). Private Governance as Regulatory Substitute or Complement? A Comparative Institutional Approach to CSR Adoption by Multinational Corporations. In C. DöRrenbächer \& M. Geppert (Ed.), Multinational Corporations and Organization Theory: Post Millennium Perspectives (Research in the Sociology of Organizations, Vol. 49, pp. 445-478). Emerald Publishing Limited.

Jamali, D. (2010). MNCs and international accountability standards through an institutional lens: Evidence of symbolic conformity or decoupling. Journal of Business Ethics, 95(4), 617-640. https://doi.org/10.1007/s10551-010-0443-z

Karassin, O., \& Bar-Haim, A. (2016). Multilevel corporate environmental responsibility. Journal of Environmental Management, 183, 110-120. https://doi.org/10.1016/j.jenvman.2016.08.051

Karnani, A. (2007). The mirage of marketing to the bottom of the pyramid: How the private sector can help alleviate poverty. California Management Review, 49(4), 90-111. https://doi.org/10.2307/41166407

Kercher, K. (2007). Corporate Social Responsibility: Impact of globalisation and international business. Retrieved from http://epublications.bond.edu.au/cgej/4

Kotter, J. P. (2008). Corporate culture and performance.The Free Press.

KPMG. (2013). The KPMG survey of corporate responsibility reporting 2013, KPMG International. Retrieved from

https://assets.kpmg.com/content/dam/kpmg/pdf/2015/08/kpmg-survey-of-corporate-responsibility-reporting -2013.pdf

Kundu, S. C., \& Gahlawat, N. (2015). Effects of CSR Focused HRM on Employees Satisfaction: A Study of Indian Organisations. Journal of Strategic Human Resource Management, 4(2), 42-48. https://doi.org/10.21863/jshrm/2015.4.2.007

Lenox, M. J., \& Nash, J. (2003). Industry self-regulation and adverse selection: A comparison across four trade association programs. Business Strategy and the Environment, 12(6), 343-356. https://doi.org/10.1002/bse.380

Levy, D. L., \& Brown, H. S. (2012). The Global Reporting Initiative, Promise and Limitations. In D. Reed, P. Utting, \& A. Mukherjee-Reed (Eds.), Business Regulation and Non-State Actors: Whose Standards? Whose Development? (pp. 109-121). Routledge.

Ling, Y. A. N., Simsek, Z., Lubatkin, M. H., \& Veiga, J. F. (2008). Transformational leadership's role in promoting corporate entrepreneurship: Examining the CEO-TMT interface. Academy of Management Journal, 51(3), 557-576. https://doi.org/10.5465/amj.2008.32626023

Lurie, L. (2013). Employment and Social Security Laws in the Twenty First Century. Nevo Publishing, Srigim-Leon.

Matten, D., \& Moon, J. (2008). "Implicit" and "explicit" CSR: a conceptual framework for a comparative understanding of corporate social responsibility. Academy of Management Review, 33(2), 404-424. https://doi.org/10.5465/amr.2008.31193458

Meulman, J. J., Van der Kooij, A. J., \& Heiser, W. J. (2004). Principal Components Analysis with Nonlinear Optimal Scaling Transformations for Ordinal and Nominal Data. In D. Kaplan (Ed.), Handbook of Quantitative Methods in the Social Sciences (pp. 49-70). Newbury Park, CA: Sage Publications. https://doi.org/10.4135/9781412986311.n3

Millsap, R. E., \& Maydeu-Olivares, A. (2009). The SAGE handbook of quantitative methods in psychology. Sage Publications. https://doi.org/10.4135/9780857020994 
Mitchell, R. K., Agle, B. R., \& Wood, D. J. (1997). Toward a theory of stakeholder identification and salience: Defining the principle of who and what really counts. Academy of Management Review, 22(4), 853-886. https://doi.org/10.5465/amr.1997.9711022105

Montero, M. J., Araque, R. A., \& Rey, J. M. (2009). Occupational health and safety in the framework of corporate social responsibility. Safety Science, 47(10), 1440-1445. https://doi.org/10.1016/j.ssci.2009.03.002

Mudrack, P. (2007). Individual personality factors that affect normative beliefs about the rightness of corporate social responsibility. Business \& Society, 46(1), 33-62. https://doi.org/10.1177/0007650306290312

Needle, D. (2010). Business in context: An introduction to business and its environment. Cengage Learning EMEA.

Novicevic, M. M., Hayek, M., \& Fang, T. (2011). Integrating Barnard's and contemporary views of industrial relations and HRM. Journal of Management History, 17(1), 126-138. https://doi.org/10.1108/17511341111099547

O’Riordan, L., \& Fairbanks, J. (2014). Managing CSR Stakeholder Engagement: A New Conceptual Framework. Journal of Business Ethics, 125(1), 121-145. https://doi.org/10.1007/s10551-013-1913-x

OECD. (2011). Guidelines for multinational enterprises, 2011 edition. Retrieved from https://www.oecd.org/corporate/mne/48004323.pdf.

Okhmatovskiy, I., \& David, R. J. (2012). Setting your own standards: Internal corporate governance codes as a response to institutional pressure. Organization Science, 23(1), 155-176. https://doi.org/10.1287/orsc. 1100.0642

Orlitzky, M., Louche, C., Gond, J. P., \& Chapple, W. (2017). Unpacking the drivers of corporate social performance: A multilevel, multistakeholder, and multimethod analysis. Journal of Business Ethics, 144(1), 21-40. https://doi.org/10.1007/s10551-015-2822-y

Parent, M. M., \& Deephouse, D. L. (2007). A case study of stakeholder identification and prioritization by managers. Journal of Business Ethics, 75(1), 1-23. https://doi.org/10.1007/s10551-007-9533-y

Preuss, L., Haunschild, A., \& Matten, D. (2009). The rise of CSR: implications for HRM and employee representation. The International Journal of Human Resource Management, 20(4), 953-973. https://doi.org/10.1080/09585190902770893

Remišová, A., \& Búciová, Z. (2012). Measuring corporate social responsibility towards employees, Journal for East European Management Studies, 17(3), 273-291. https://doi.org/10.5771/0949-6181-2012-3-273

Robinson, P. K. (2010). Responsible retailing: The practice of CSR in banana plantations in Costa Rica. Journal of Business Ethics, 91(2), 279-289. https://doi.org/10.1007/s10551-010-0619-6

Rodriguez, J. K., \& Gomez, C. F. (2009). LA-HRM in Chile: The impact of organisational culture. Employee Relations, 31(3), 276-294. https://doi.org/10.1108/01425450910946479

Sánchez, P. E., \& Benito-Hernández, S. (2015). CSR Policies: Effects on Labour Productivity in Spanish Micro and Small Manufacturing Companies. Journal of Business Ethics, 128(4), 705-724. https://doi.org/10.1007/s10551-013-1982-x

Schein, E. H. (1985). Organizational Culture and Leadership: A Dynamic View. San Francisco. CA: Jossey Bass.

Schein, E. H. (2006). Organizational culture and leadership (3rd ed.). John Wiley \& Sons.

Sethi, S. P. (1975). Dimensions of corporate social performance: An analytical framework. California Management Review, 17(3), 58-64. https://doi.org/10.2307/41162149

Srinivasan, V., \& Arora, B. (2015). 19. Examining LA-HRM and CSR linkages in the context of emerging economies: the Indian experience. In F. Horwitz \& P. Budhwar (Eds.), Handbook of Human Resource Management in Emerging Markets (pp. 429-450).

Staehle, W., \& Schirmer, F. (1992). Lower-level and middle-level managers as the recipients and actors of human-resource management. International Studies of Management \& Organization, 22(1), 67-89. https://doi.org/10.1080/00208825.1992.11656576

Strand, R. (2011). Exploring the role of leadership in corporate social responsibility: A review. Journal of Leadership, Accountability and Ethics, 8(4), 84-96.

Sumetzberger, W. (2005). Managing human resources in a multinational context. Journal of European Industrial 
Training, 29(8), 663-674. https://doi.org/10.1108/03090590510627120

Thornton, D., Kagan, R. A., \& Gunningham N. (2009). When social norms and pressures are not enough: environmental performance in the trucking industry. Law \& Society Review, 43(2), 405-436. https://doi.org/10.1111/j.1540-5893.2009.00377.x

Turker, D. (2009). Measuring corporate social responsibility: A scale development study. Journal of Business Ethics, 85(4), 411-427. https://doi.org/10.1007/s10551-008-9780-6

van Erp J. (2011). Naming and shaming in regulatory enforcement. In C. Parker \& V. Lehmann-Nielsen (Eds.), Explaining Compliance, Business Responses to Regulation (pp. 322-343). Edward Elgar: Cheltenham. https://doi.org/10.4337/9780857938732.00023

Vinzi, V. E., Henseler, J., \& Wang, H. (Eds). (1999). Handbook of partial least squares: concepts, methods and applications. Springer Handbooks of Computational Statistics Series, Berlin.

Vogel, D. (2007). The market for virtue: The potential and limits of corporate social responsibility. Brookings Institution Press.

Waddock, S. A., \& Graves, S. B. (1997). The corporate social performance-financial performance link. Strategic Management Journal, 303-319. https://doi.org/10.1002/(SICI)1097-0266(199704)18:4<303::AID-SMJ869>3.0.CO;2-G

Waldman, D. A., \& Siegel, D. (2008). Defining the socially responsible leader. The Leadership Quarterly, 19(1), 117-131. https://doi.org/10.1016/j.leaqua.2007.12.008

Waldman, D. A., de Luque, M. S., Washburn, N., House, R. J., Adetoun, B., Barrasa, A., ... others. (2006). Cultural and leadership predictors of corporate social responsibility values of top management: A GLOBE study of 15 countries. Journal of International Business Studies, 37(6), 823-837. https://doi.org/10.1057/palgrave.jibs.8400230

Weaver, G. R., Trevino, L. K., \& Cochran, P. L. (1999). Corporate ethics programs as control systems: Influences of executive commitment and environmental factors. Academy of Management Journal, 42(1), 41-57.

Wilburn, K., \& Wilburn, R. (2013). Using global reporting initiative indicators CSR programs. Journal of Global Responsibility, 4(1), 62-75. https://doi.org/10.1108/20412561311324078

\section{Notes}

Note 1. When scale items are different in their contents and measures, the recommended scaling method is Optimal Scaling, using IBM SPSS optimal scaling procedure. This method combines different measures into a multi-item scale (Meulman et al., 2004).

Note 2. See note 1.

\section{Copyrights}

Copyright for this article is retained by the author(s), with first publication rights granted to the journal.

This is an open-access article distributed under the terms and conditions of the Creative Commons Attribution license (http://creativecommons.org/licenses/by/4.0/). 